\title{
ROSEWOOD PLANTATION PROJECT: REPORT TO UNIT OWNERS
}

\author{
Celeste B. Porter
}

February 1982

NOTICE

PORTIONS OF THIS REPORT ARE IUJEGIBLE. It has been reproduced from the best available copy to permit the broadest possible availab111ty.

prepared for

\section{U.S. DEPARTMENT OF ENERGY}

under contract number DE-ACO2-79CS30166

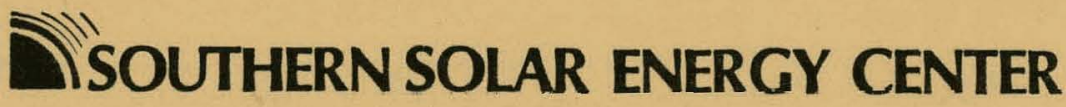

OPERATED WITH SUPPORT FROM THE U.S. DEPARTMENT OF ENERGY

61 PERIMETER PARK ATLANTA, GEORGIA 30341

$404458-8765$ 


\section{DISCLAIMER}

This report was prepared as an account of work sponsored by an agency of the United States Government. Neither the United States Government nor any agency Thereof, nor any of their employees, makes any warranty, express or implied, or assumes any legal liability or responsibility for the accuracy, completeness, or usefulness of any information, apparatus, product, or process disclosed, or represents that its use would not infringe privately owned rights. Reference herein to any specific commercial product, process, or service by trade name, trademark, manufacturer, or otherwise does not necessarily constitute or imply its endorsement, recommendation, or favoring by the United States Government or any agency thereof. The views and opinions of authors expressed herein do not necessarily state or reflect those of the United States Government or any agency thereof. 


\section{DISCLAIMER}

Portions of this document may be illegible in electronic image products. Images are produced from the best available original document. 


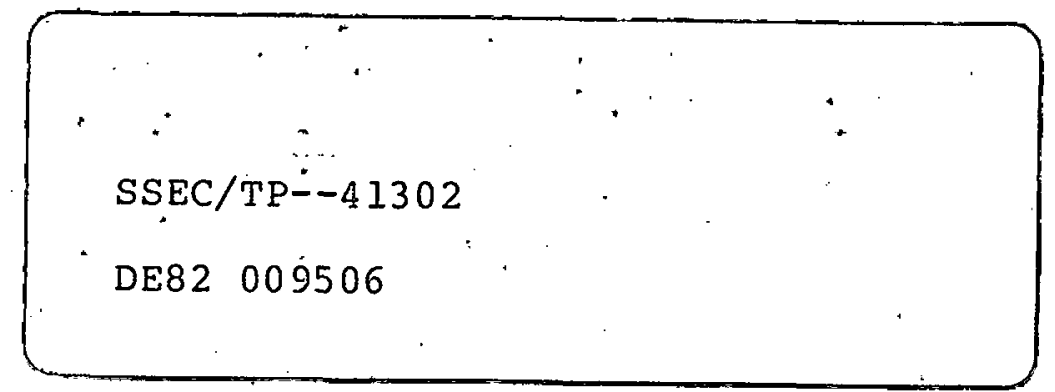

DISCLAIMER

This report was prepared as an account of work sponsored by the Southern Solar Energy Center, a contractor of the United States Government. Neither the Southern Solar Energy Center, the United States Government, nor any agency thereof, nor any of their employees, wakes any warranty, express or implied, or assumes any legal liability or responsibility for the accuracy, completeness, or usefulness of any information, apparatus, product, or process disclosed, or represents that its use would not infringe privately owned rights. References herein to any specific comercial product, process, or service by trade name, trademark, manufacturer, or otherwise, does not necessarily constitute or imply its endorsement, recommendation, or favoring by the Southern Solar Energy Center, the United States Government, or any agency thereof. The views and opinions of authors expressed herein do not necessarily state or reflect those of the Gouthern Solar Energy Center, the Uaited states Government, nor any agency thereof.

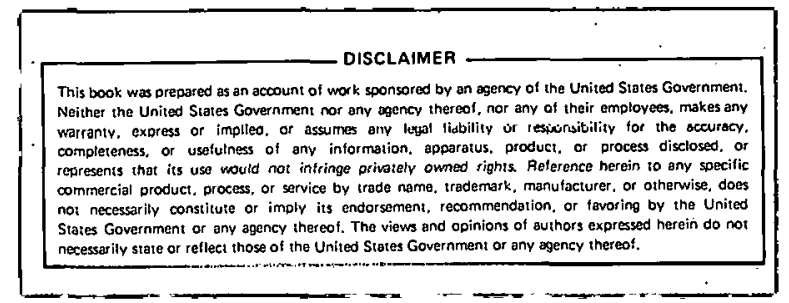


Rosewood Plantation Project:

Report to Unit Owners

\author{
Celeste B. Porter
}

February 1982 


\section{TABLE OF CONTENTS}

Page:

Thèrmal Performance - Winter 1980-81 ............. I

Site Plan - unit clusters studied for energy consumption .......................... 3

Graph - monthly energy consumption .............. 4

Rosewood Plantation - floor plans and

photographs of south-facing units $\ldots \ldots \ldots \ldots \ldots \ldots . .5$ 
Rosewood Plantation

Thermal Performance - Winter 1980-81

Rosewood Plantation, a multifamily condominiu development located in north Atlanta, Georgia, is the result of a cooperative design effort between J.T. Holding Company; Zachary Henderson, architect; and the Southern Solar Energy Center (SSEC). Approximately one year after the opening of Rosewood Plantation, SSEC reviewed the project and studied the thermal performance.

Only two unit clusters with south-facing condosiniums had been occupied through the winter of 1980-81. With the cooperation of the developer, the owners, and the utility company, the gas bill history was obtained and analyzed. Of those participating, 10 units had been occupied for six months $(11 / 80-4 / 81)$ and 14 units had been occupied for five months $(12 / 80-4 / 81)$, which was considered a sufficient number to obtain verifiable data. A site plan of these units is included in the Appendix least-, south-, and west-facing units in U-shaped cluster).

A11 of these units have natural gas heat/hot water service, $R-30$ insulation (roof), R-18 insulation (walls), therma-pane double-hung wooden windows, energy-efficient exterior doors, and a wood-burning fireplace with gas log lighter.

Additional data were obtained for the study to determine thermal performance (Btu/DD/ft ${ }^{2}$ ) of each unit. In order to compare buildings of different sizes in different locations it is necessary to remove parameter effects from the comparison; $B t u / D D / \mathrm{ft}^{2}$ is such a measure. The measurement for heat consumption (Btu) was calculated using information given by the utility company. To obtain the amount of gas used for space heating only, the average amount of hot water usage was approxinated for each unit and subtracted from the total amount of gas used per billing period. From this amount, the consumption figures were calculated. The degree days (DD) were determined per billing period for Atlanta from daily temperature records in "Local Climatological Data" by the National Oceanic and Atmospheric Administration at the National Climatic Center in Asheville, North Carolina. Degree days measure the severity of the heating season in a particular locale. Square footage $\left(\mathrm{ft}^{2}\right)$ of each unit was obtained from the architect's plans.

The following observations were made from monthly $B$ tu/DD/ft ${ }^{2}$ figures weighted according to monthly degree days. There were tremendous variations between the best to worst units in terms of energy consumption levels. The units represent good energy-conserving construction laverage 9.52 Btu/DD/ft $\mathrm{t}^{2}$ and use less than one-half the energy projected in the proposed BEPS standard for an average house of the same size (21 Btu/DD/ft2). However, the average energy consumption was twice what was originally anticipated. The difference from what was assumed and the actual can be partly accounted for by the infiltration caused by the construction technique used to apply wall insulation and the omission of sealant during construction. It is important to remember that the energy consumption level predicted was a maximum expectation that could be achieved with the given design constraints. 
Some units performed close to the predicted level, and one unit was even better than predicted. Given that the units were similarly constructed, occupant lifestyle greatly affected the performance of the units. The best four units averaged $6.06 \mathrm{Btu} / \mathrm{DD} / \mathrm{ft}^{2}$ while the worst four units averaged 12.69 Btu/DD/ft2. Different household habits account for the variation, including frequent travel, thermostat settings, and hours spent at home. Use of a fireplace increases consumption levels; if the damper is not closed after use, heat is continuously lost. The slightly increased consumption of all the units during December (holidays, when most people are home) is probably attributed to frequent use of the fireplace.

As anticipated, the interior units performed better than end units on the average because of greater protection from the weather and less opportunity for infiltration. The monthly average energy consumption for all the units followed expectations, peaking in December with a following decline, in accordance with the heating degree day pattern. On the average, a slight increase of energy consumption occurred during Apri1, probably due to occupant lifestyle. (See Appendix C.)

The south-facing units without bay windows used less energy than those facing east or west. However, in comparing the two clusters, one set of east-facing units performed better than the other, which could be attributed to either some variation in construction or occupant lifestyle. The participating units with south-facing bay windows were end units and had above average energy consumption. Any solar heat gained was offset by the combination of the infiltration associated with the bay window and end units and occupant lifestyle. Nonetheless, the cooling season performance of the south-facing units should be better than the other units; south walls receive less solar radiation during the summer and are readily shaded by fixed roof overhangs.

In conclusion, the units represent good energy-conserving construction as evidenced by their themal performance. The use of sealant and more careful installation of wall insulation would have further improved the performance. As in any residence, the occupant lifestyle greatly effects the level of thermal performance achieved. 


\section{ROSEWOOD PLANTATION SITE PLAN}

BY RIVER PLANTATION COMPANY

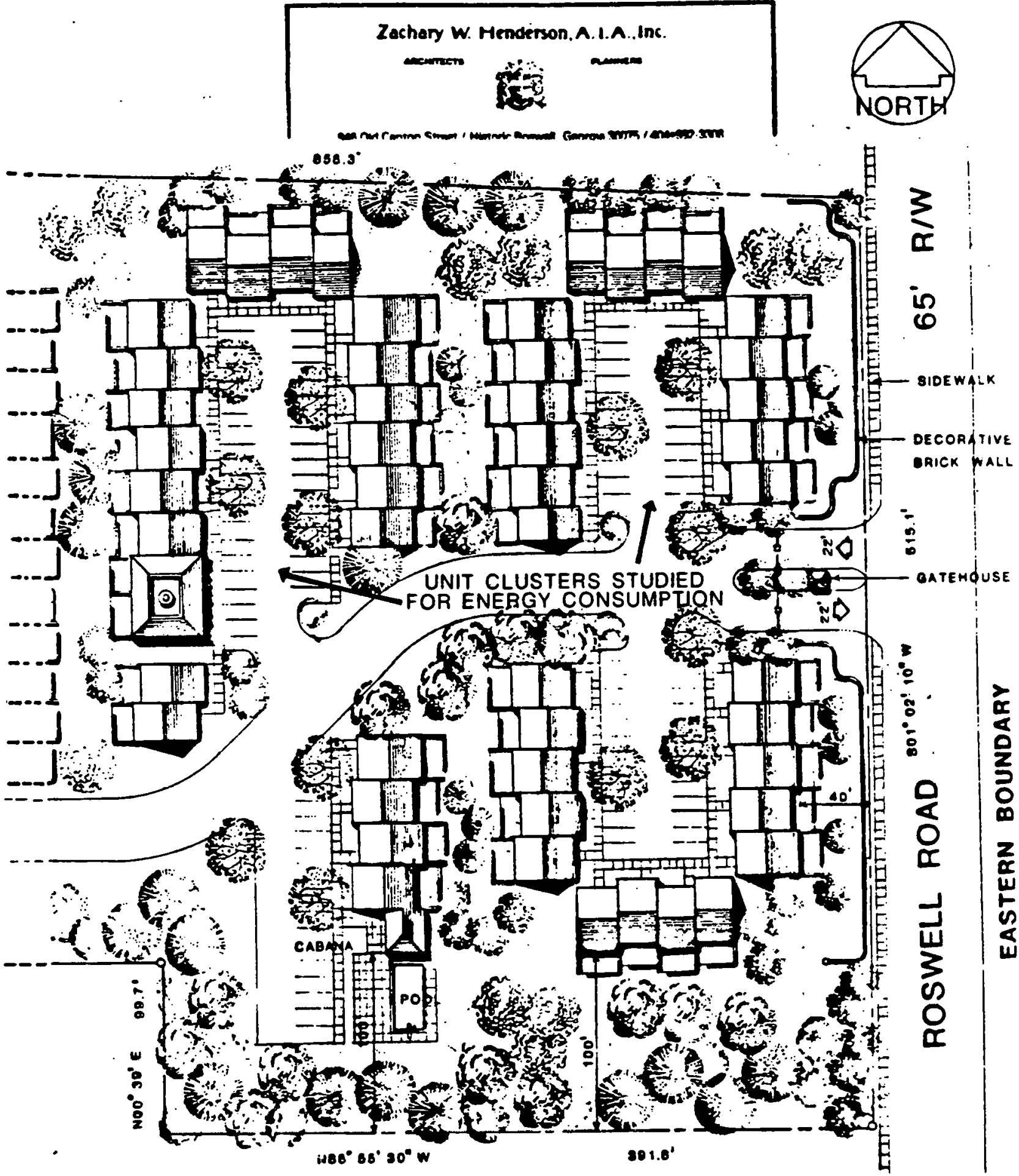

TWO \& THREE BEDROOM TOWNHOUSES

105 UNITS (9.6UNITS PER ACRE)

10.94 ACRES

210 PARKING SPACES 


\section{- MONTHLY ENERGY CONSUMPTION ROSEWOOD PLANTATION}

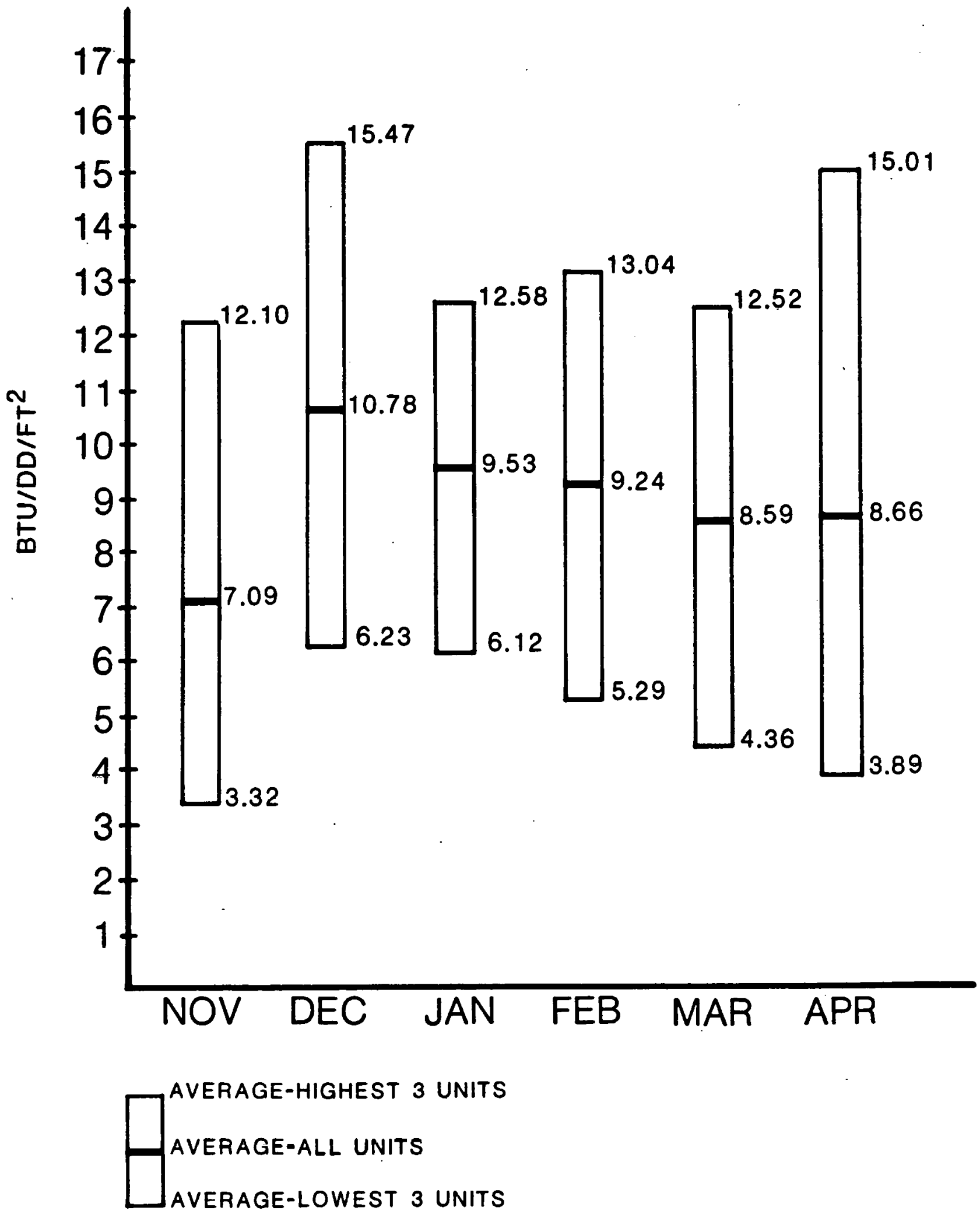


ROSEWOOD PLANTATION

FLOOR PLANS AND PHOTOGRAPHS

OF SOUTH-FACING UNITS 


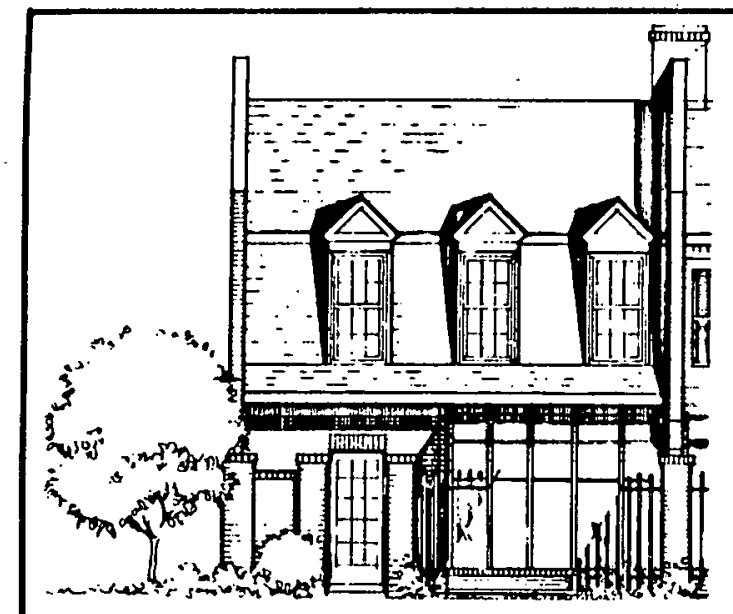

REAR ELEVATION

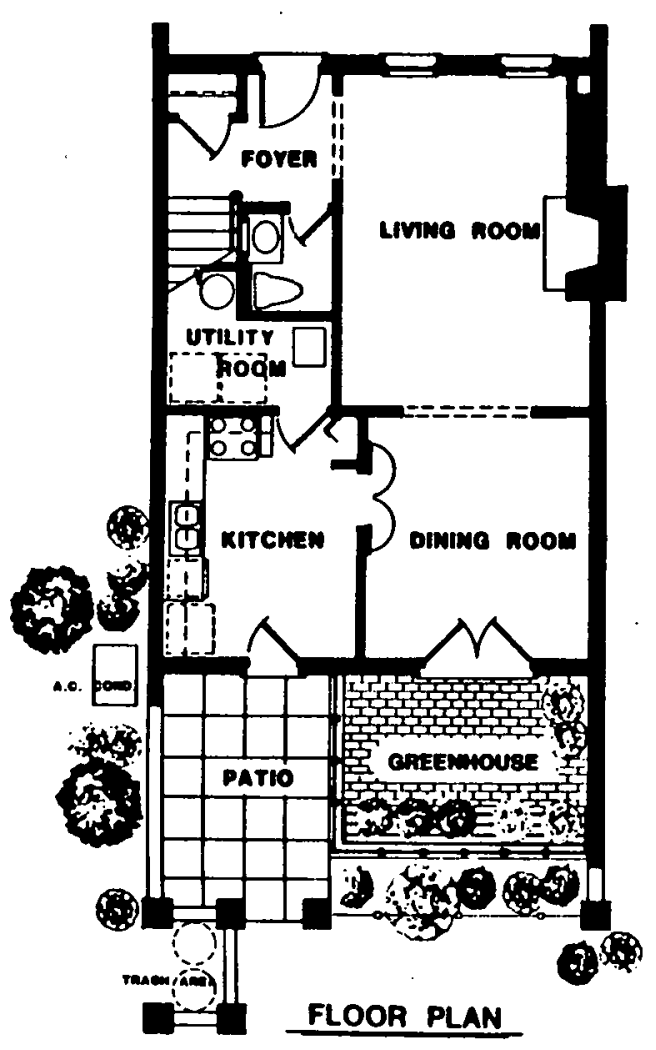

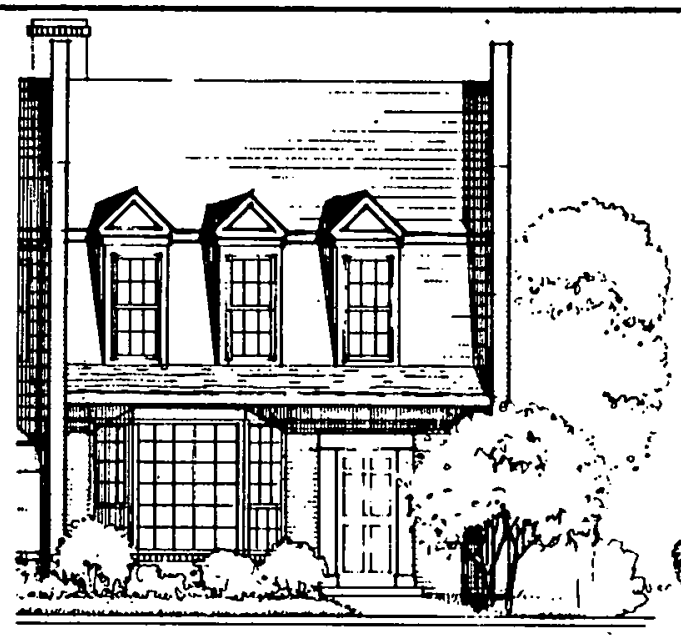

FRONT ELEVATION

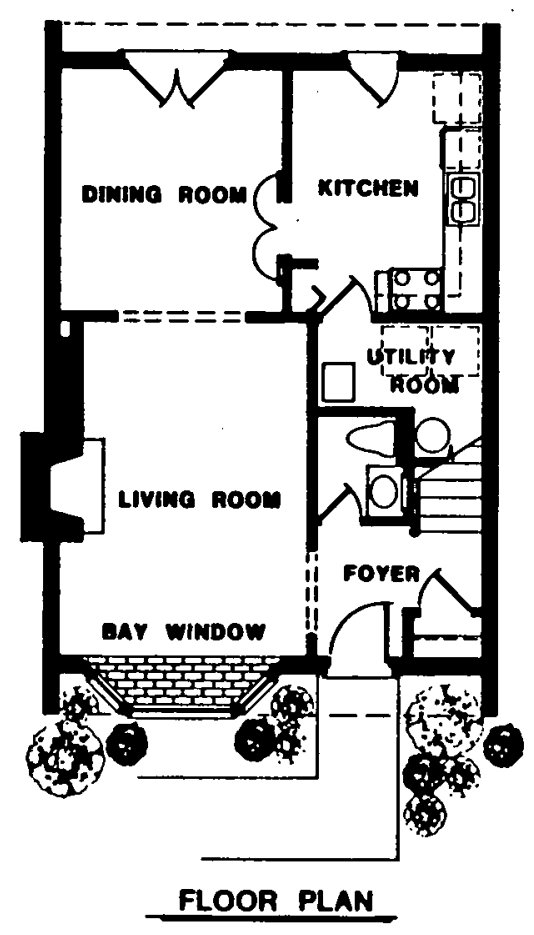

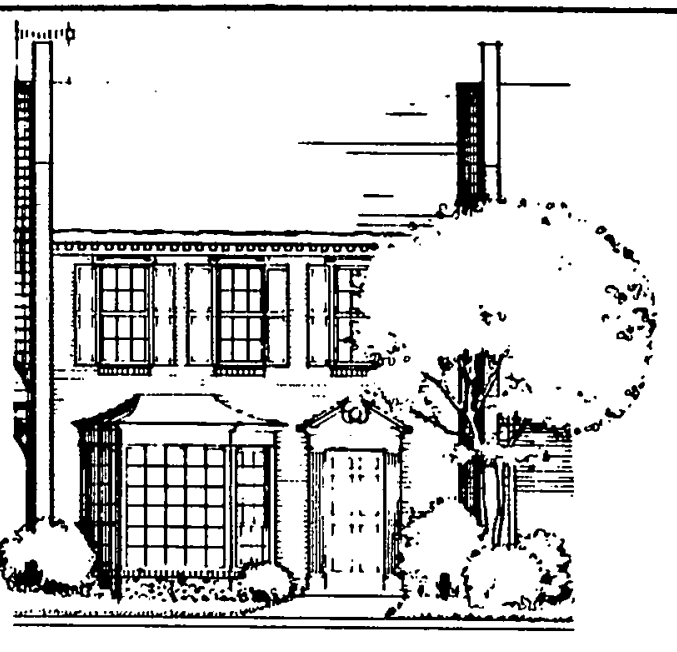

FRONT ELEVATION

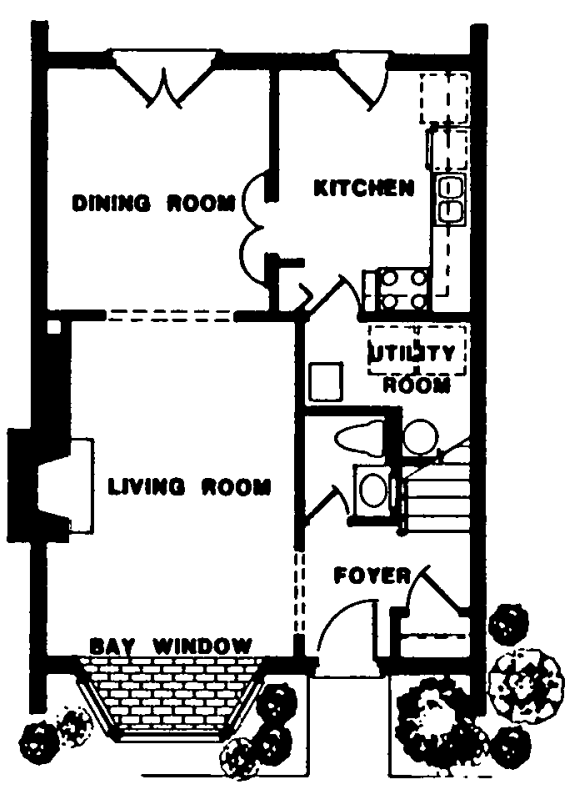

FLOOR PLAN

\begin{tabular}{|c|c|c|c|c|c|}
\hline & $\begin{array}{l}\text { PASSI } \\
\text { SOLAF }\end{array}$ & $\begin{array}{l}\text { VE } \\
\text { UNITS }\end{array}$ & \multirow{2}{*}{\multicolumn{2}{|c|}{$\begin{array}{c}\text { ROSEWOOD PLANTATION } \\
\text { ROSWELL ROAD } \\
\text { atLANTA. GEORgIA }\end{array}$}} & \multirow{2}{*}{ Iether W Hendmon, A.I.A.IIr } \\
\hline & 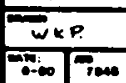 & isit & & & \\
\hline
\end{tabular}




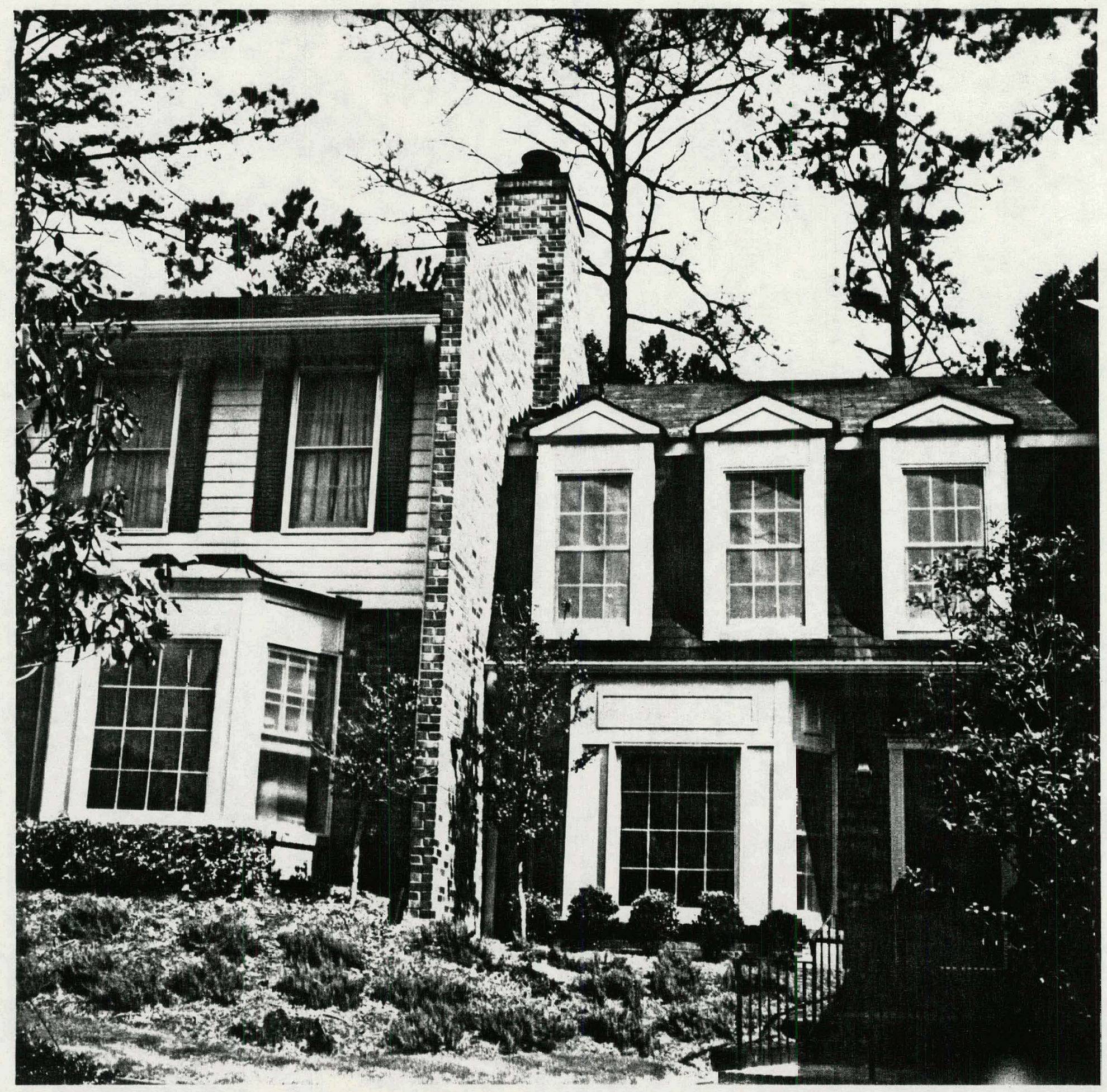




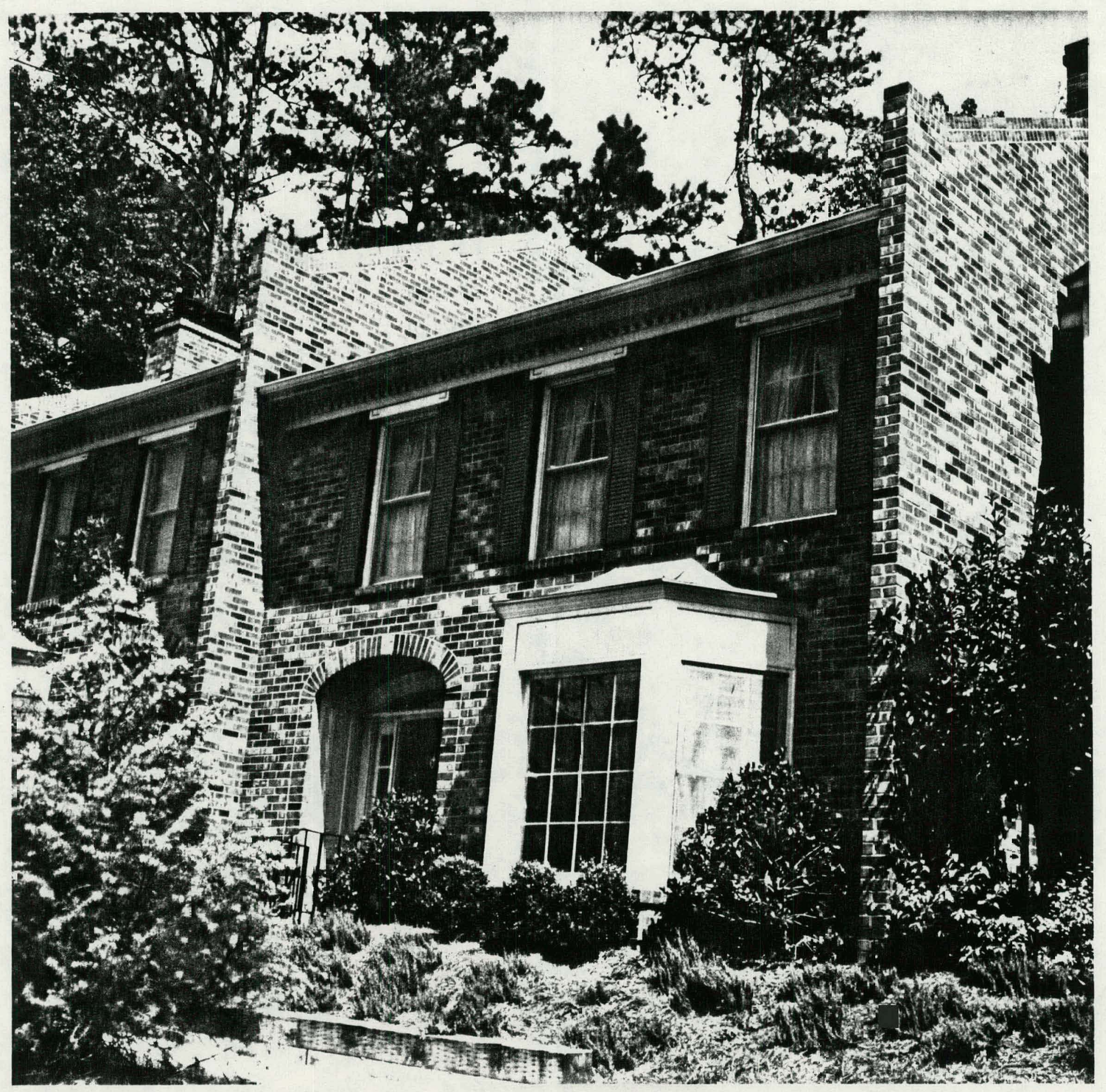




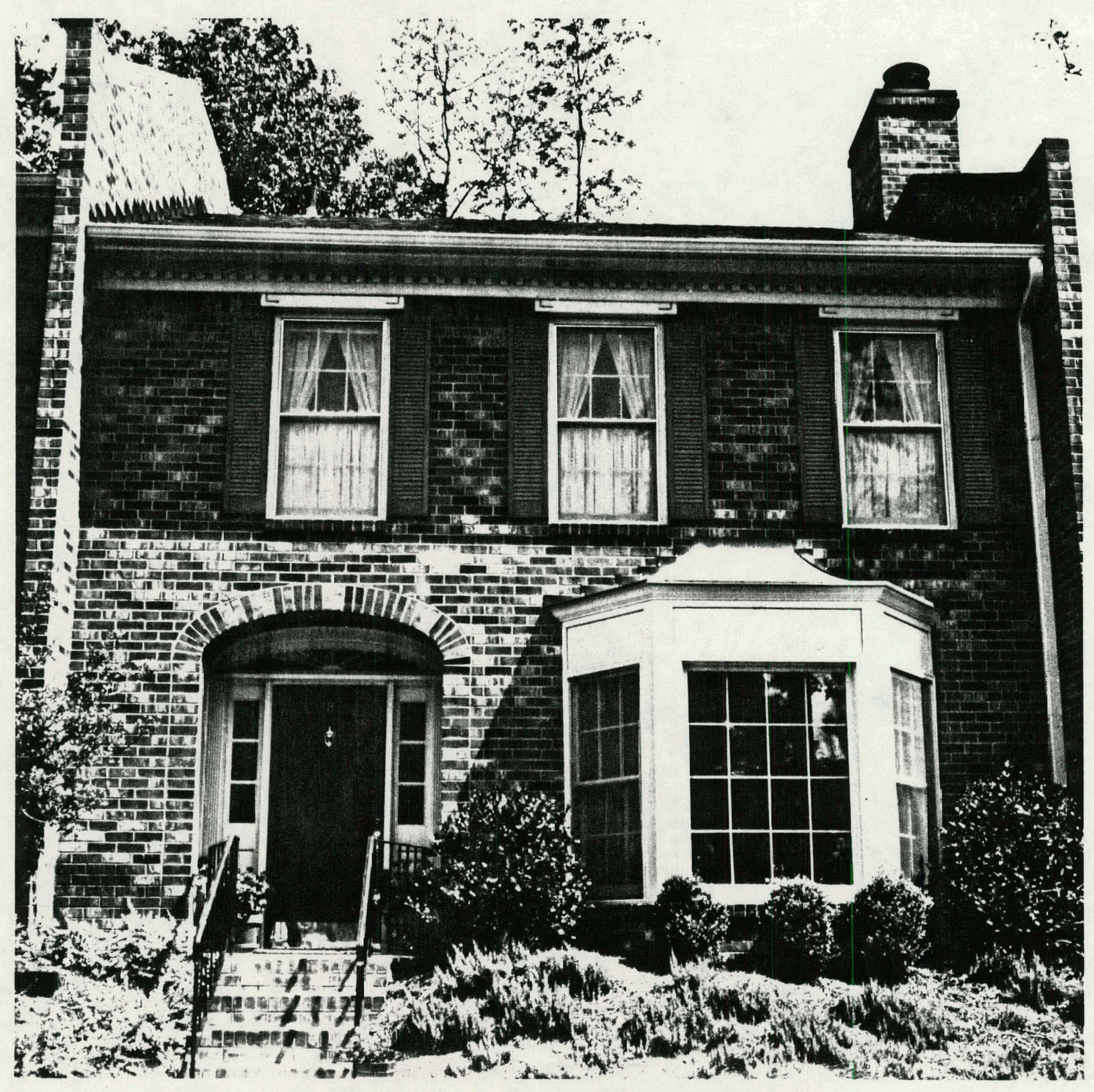

